\title{
Crimes do texto, crimes verdadeiros: a máfia na voz de Leonardo Sciascia
}

Crimes in the text, real crimes: The Mafia in the voice of Leonardo Sciascia

Júlio Pimentel Pinto*

\section{Resumo}

Nas entrevistas ou nos pronunciamentos parlamentares que realizou - assim como em sua ficção - o escritor siciliano Leonardo Sciascia denunciou incessantemente a máfia. Para ele, a hegemonia do crime organizado e suas articulações na política institucional impediam o acesso à verdade e à justiça. Coerentemente, suas peculiares narrativas policiais apresentam crimes sem solução, detetives derrotados, silêncios e omissões. Associando os crimes do texto e os crimes verdadeiros, Sciascia desenha, assim, o perfil da Sicília e, de forma mais ampla, da Itália.

Palavras-chave: Leonardo Sciascia; máfia; narrativa policial.
Abstract

In his interviews or parliamentary speeches - as well as in his fiction - the Sicilian writer Leonardo Sciascia ceaselessly denounced the mafia. According to him, the hegemony of the organized crime and its connections in institutional politics were responsible to prevent the access to truth and justice. Consistently, his distinctive detective stories present unsolved crimes, defeated detectives, silences and omissions. Thus, through the crimes in the text and the real crimes, Sciascia draws the profile of Sicily and, more widely, the profile of Italy.

Keywords: Leonardo Sciascia; mafia; detective stories.

Jamaisse saberáqualquerverdade sobre os delitos que tenham, ainda que minimamente, relação com a gestão do poder.

Leonardo Sciascia

\section{I.}

Quando Italo Calvino acabou de ler A ciascuno il suo (A cada um o seu), de Leonardo Sciascia, resumiu sua curiosa impressão numa carta ao autor: "Li seu policial que não é um policial com a paixão com que se leem os policiais, e até

\footnotetext{
* Departamento de História, Universidade de São Paulo (USP). São Paulo, SP, Brasil. juliop@uol.com.br ${ }^{1}$
} 
com o divertimento de ver como o policial é desmontado ou, ao contrário, como é demonstrada a impossibilidade do romance policial no contexto siciliano". ${ }^{2}$

Mesmo uma leitura rápida desse romance de Sciascia permite encontrar todos, ou quase todos, os procedimentos do gênero policial em sua matriz europeia, analítica: o detetive está presente e seu papel é fixo, ele é excepcionalmente racional e visionário, é incorruptível, infalível, austero e vê o que os outros não veem. Também está lá seu auxiliar - uma espécie de Sancho Pança: aquele que não alcança o gênio do detetive, mas age enquanto o detetive pensa. O assistente é uma figura positiva, mas secundária, com quem o leitor tende a se identificar: aceita a condição de inferioridade em relação ao detetive, assume seu caráter de espectador, mas não se mantém puramente passivo. Ainda de acordo com as matrizes genéricas do policial, o terreno em que o crime ocorreu (ou vai ocorrer) é esquadrinhado, as pistas são gradativamente reveladas, o perfil psicológico dos participantes é construído de forma sólida. Identificam-se possíveis prenúncios do crime e a história vai-se conformando logicamente até que o exercício cerebral do detetive seja exposto, numa manifestação da razão e da verdade. ${ }^{3}$

O desfecho das histórias policiais de Sciascia, porém, são incompletos: o crime não leva a nenhum castigo porque o aparato político e os rituais sociais historicamente constituídos na Sicília impedem a revelação da verdade ou a celebração do gênio analítico e dedutivo. O Capitão Bellodi, investigador de Il giorno della civetta ( $O$ dia da coruja), tem um diálogo decisivo com um chefe mafioso, dom Mariano, e o confronta com as provas de sua ação criminosa:

"Muito, muitíssimo dinheiro, de proveniência, digamos, incerta... Veja: estas são as cópias fotográficas das fichas, em seu nome e no de sua filha, encontradas no banco. Como vê, procuramos não apenas nas agências de sua região: fomos até Palermo. Muito, muitíssimo dinheiro: o senhor pode explicar sua origem?"

"E o senhor, pode?", perguntou impassível Dom Mariano.

“Tentarei: porque no dinheiro que o senhor tão misteriosamente acumula é preciso procurar as razões dos crimes que estou investigando: e estas razões precisam ser de algum modo esclarecidas nos documentos que o acusarão pelo homicídio... Tentarei... Mas o senhor deve também dar uma explicação ao fisco, a quem transmitiremos esses dados..."

Dom Mariano fez um gesto de desprezo.

... "Vê?”, disse o capitão, "Há muitas coisas a esclarecer, que o senhor deve explicar..."

De novo, dom Mariano fez um gesto de desprezo. 
O diálogo tem caráter revelador para Bellodi, que resume num pensamento sua decepção e constata amargamente que

"Esta é a questão" pensou o capitão "à qual seria preciso dar atenção. É inútil tentar condenar penalmente um homem como este aqui: jamais haverá provas suficientes, o silêncio dos honestos e dos desonestos o protegerá sempre. E é inútil, além de perigoso, tentar uma suspensão dos direitos constitucionais ... Em qualquer outro país do mundo, uma evasão fiscal como a que estou constatando seria duramente punida: aqui, dom Mariano ri de tudo, sabe que não terá grande dificuldade de misturar as cartas".

O trecho é exemplar do policial de Sciascia. Ele assume, para o leitor, sentido irônico e amargamente cômico: das pistas à razão chega-se à verdade - mesmo se não plena -, mas ela é silenciada. O cômico rapidamente se transmuta em representação de uma realidade política dramática, de uma "justiça traída" que, além da questão política, é um problema moral. No lugar da consolação e da redenção que a narrativa policial normalmente traz, Sciascia oferece desconforto e desassossego - percepção angustiada que anuncia estranhamento e familiaridade.

Talvez por isso Sciascia tenha afirmado, certa vez, que o milanês Carlo Emilio Gadda "escreveu o mais absoluto policial jamais escrito, um policial sem solução". ${ }^{5}$ Afinal, quando o tecido social e político está puído - é o que sugere Sciascia - a investigação não se divisa com revelação e a narrativa policial se confunde com a ação política, que mostra que "a lei" está comprometida com o crime e é leniente ou impotente diante dele; a força criminosa - no caso, a máfia - é maior. E foi da máfia que Sciascia falou: alertou para sua existência, na década de 1950, quando a palavra era silenciada por muitos italianos que, de alguma forma, estabeleciam relações diretas com a organização criminosa: partidos políticos, setores social e politicamente dirigentes dentro e fora da Sicília, empresários envolvidos em grandes operações financeiras ou que atuavam em setores com forte presença de braços mafiosos (parte da construção civil, por exemplo), segmentos da imprensa local e nacional.

Nascido em 1921, na pequena Racalmuto, interior da Sicília, Sciascia publicou seus primeiros textos no pós-Segunda Guerra Mundial. A Itália vivia dias difíceis. Estava esfacelada pela derrota e pela devastação, os partidos e instituições políticas reinventavam-se a duras penas e debatiam as atitudes de seus membros durante o período de hegemonia fascista. Na Sicília, o cenário 
era igualmente complexo. A ilha enfrentara, além do fascismo, o vigor brutal dos ataques aliados e agora atravessava um duro processo de reconstrução.

A própria máfia siciliana passara por transformações durante a guerra: perdera poder político e social; parte de seus membros transferira-se para a América; diversos agrupamentos, ou famílias, reestruturaram sua ação e seus negócios dentro da ilha, para sobreviver à repressão sob o fascismo. Ao final do conflito, no entanto, a organização criminosa encontrou espaço mais amplo de atuação: apresentou-se como vítima do fascismo e atuou nos interstícios de uma política desorganizada. O vínculo da ilha com a Itália continental era, nesse momento, fluido, os partidos antifascistas estavam fragilizados, as ideias separatistas grassavam e a criminalidade crescia, descontrolada.

Alguns relatórios das autoridades públicas chegavam a sugerir o estabelecimento de relações com o crime organizado, que, além de contribuir para o restabelecimento da ordem, podia garantir, por meio do acesso mais fácil ao mercado clandestino, o abastecimento alimentar da ilha, então seriamente comprometido (Lupo, 2002, p.98). A máfia ingressava com força na administração pública, compunha alianças e firmava compromissos que lhe garantiam atuação vital na recuperação da Sicília. A explicitação de seu controle manifestava-se de maneira mais regular e intensa do que nos anos de guerra: atentados rumorosos, presença direta nos grandes partidos políticos, candidaturas e vitórias eleitorais, controle direto de prefeituras e de cargos políticos no primeiro escalão.

Justamente em meio a esse cenário, Sciascia publicou seu primeiro livro, Favolle della ditadura (Fábulas da ditadura), em 1950. A obra reunia pequenos textos, em formato de fábulas, com críticas políticas ao fascismo. Ele iniciava, assim, o trabalho que mobilizou toda sua vida, até a morte, em 1989: escrever e engajar-se politicamente, muitas vezes deixando indistinguíveis as fronteiras das duas atuações. $\mathrm{Na}$ contramão do silêncio de tantos, Sciascia expôs sua denúncia política sob a forma de histórias policiais e definiu uma forma peculiar para a narrativa policial na Sicília.

\section{II.}

As origens da máfia são controversas. A palavra é mencionada desde a metade do século XIX - quando se instalou um longo e jamais encerrado debate sobre sua origem e atuação - e seu sentido migrou ao longo da história, significando, entre outras coisas, proteção (daí a célebre ideia de "padrinho"). O próprio Sciascia brincou em "Filologia", relato que integra $O$ mar cor de 
vinho (Sciascia, 2001d), com a variedade de interpretações acerca da instituição e da palavra. ${ }^{6}$ Stefano Salis considera o conto "altamente emblemático" e seu título, exemplar, porque

Filologia é a arte da reconstrução de um texto ausente, é o complexo de investigação que visa restabelecer a forma originária de um texto (livrando-o de erros e alterações), interpretá-lo, definir (quando há dúvidas) sua autoria, o período e o ambiente cultural; é a arte de reparação do que foi perdido, mas também da redescoberta do que é subterrâneo. E não apenas do que um texto diz, mas também daquilo que não diz, que teria dito, que poderia ter dito ... [Em "Filologia", o conto] A confusão reinará soberana... e tanto mais quanto se tenta precisar a própria essência daquilo de que se fala - no caso, a máfia. $\mathrm{O}$ texto autoriza uma disputa intrínseca, ou melhor, a prevê e talvez a sugira. Transfere-a para a realidade, que deverá ser lida, daquele momento em diante, também sobre a base que aquele texto sugere ... Aqui - em "Filologia" - está toda a sagacidade e a sabedoria, mas, preciso dizer, o triste reconhecimento da escritura e de seu valor (o valor da escritura) que Leonardo Sciascia sempre conheceu. (Salis, 2006, p.79-82)

O conto destaca um momento-chave na história recente da Itália, anos 1960, quando a expressão voltava ao vocabulário da política, da polícia e da mídia. O reconhecimento da palavra na história de Sciascia equivale a um aprendizado do significado que ela pode assumir na experiência vivida - o lugar que seria reservado à máfia numa sociedade que sabia de sua existência regular e ininterrupta desde o século XIX, mas a negava no discurso oficial da primeira metade do século XX, especialmente sob o fascismo, e também após a derrota italiana na Segunda Guerra Mundial.

As sucessivas revelações de ações mafiosas, nas narrativas de Sciascia, desde a década de 1950, abriram espaço para a reaparição da palavra, que deixara de ser mencionada na imprensa: ele ajudava, em parte, o nascimento de um movimento político que desembocou na criação da Comissão Antimáfia no final de 1962, e em sua instalação no ano seguinte. ${ }^{7}$ No conto, dois mafiosos conversam sobre a origem do termo e como devem se comportar caso sejam convocados a comparecer perante a Comissão. Em tom jocoso, o diálogo repassa a bibliografia sobre o tema e as diversas acepções da palavra; prevalece o tom irônico da narração e a caracterização do cinismo dos personagens e das relações internas da organização. Quase duas décadas depois da publicação do texto, e durante uma de suas intervenções parlamentares (Sessão de 26 fev. 
1980), Sciascia relembrou o conto para demonstrar a ainda precária percepção da realidade mafiosa:

[Filologia] era um conto, quase uma brincadeira meio paradoxal, mas, na verdade, mostra o que aconteceu. Limitamo-nos à filologia, à sociologia e, 18 anos depois, ainda estamos aqui, falando de um fenômeno que, em vez de diminuir, vimos crescer. (in Camilleri, 2009, p.58)

Apesar do importante papel político de suas denúncias, a concepção de máfia que aparece no conjunto da obra de Sciascia não é original. Ele retoma noção do final do século XIX, que a definia como uma associação destinada a defender os valores sicilianos contra a modernização e a vitória do projeto político nortista de unificação italiana - uma espécie de resistência de um mundo tradicional, da "velha Sicília". Sua referência principal é um importante etnólogo da década de 1880, o palermitano Giuseppe Pitrè, que defendeu a ideia de que a máfia, originalmente, "não é seita nem organização, não tem regulamentos nem estatutos ... o mafioso não é um ladrão, não é um malandro ... a máfia é a consciência do próprio ser, o exacerbado conceito da própria força individual ... daí a intolerância pela superioridade e, pior ainda, pela prepotência alheia". ${ }^{8}$

Pitrè afirmou que a palavra-chave que regula as relações internas da máfia, omertà, derivaria de uomo e designaria aquele que reage sem recorrer ao Estado, pois é sobretudo viril: uma forma peculiar de resistir às interferências supostamente indevidas do recém-formado Estado italiano e de sua ação violenta e repressiva contra a autonomia siciliana. Máfia, protetora da ilha; mafiosos, os valorosos sicilianos que não toleravam a interferência "continental" e externa. Após a década de 1860, o sentido positivo do termo se perdeu, ressalvou Pitrè, e a máfia assumiu dimensão clandestina e negativa, associando-se ao banditismo, sem no entanto deixar de manter o papel anterior de recusa política do Estado italiano e da unificação italiana comandada pelo norte.

A apologia regionalista de Pitrè, embora questionada por outros linguistas e autores, foi extremamente influente em representações e análises posteriores da máfia, sua origem e seu papel. Independentemente de ela exercer, ou não, o papel de mantenedora das tradições sicilianas, a recorrência da imagem revela o reconhecimento coletivo das perdas a que a ilha foi submetida quando incorporada à Itália unida e a persistência de um claro e real desnível de comunicação entre a Sicília e o Estado nacional. 
Sciascia se insere, em linhas gerais, nessa interpretação: reconhece a motivação histórica do sentimento "anti-Estado" e da busca siciliana por um "espelho da sociedade tradicional" e por traços identitários capazes de unificar a população local e, sobretudo, distingui-los dos continentais. Em um de seus pronunciamentos parlamentares de 1980 (Sessão de 6 mar. 1980), Sciascia reitera o sentido histórico da instituição:

A boa sociologia, a boa filologia foi feita, para começar, pelo procurador-geral de Trapani, creio, em 1837, que, num relatório, descrevia a máfia tal como a conhecemos hoje, e era uma máfia de procuradores do rei, de secretários comunais e de padres. Depois de dom Pietro C. Ulloa, muitos outros tentaram definir corretamente a máfia, mas devemos sobretudo a um inglês a definição da máfia que eu considero um ovo de Colombo: a máfia é, diz ele, a única revolução burguesa que a Sicília poderia ter. Assumamos agora que essa revolução foi feita e que essa burguesia está no poder. (in Camilleri, 2009, p.66)

A questão que a máfia coloca, no passado e no presente, é, portanto, a da apropriação criminosa do Estado italiano. A questão já aparecera, em 1977, em meio à polêmica provocada pelas ações terroristas das Brigadas Vermelhas. Sciascia declarara, então, que não compreendia o Estado de maneira abstrata nem se opunha abstratamente a ele; refutava o que ele representava como espaço de alianças e negociações espúrias de políticos corruptos: não se colocava, portanto, nem do lado dos terroristas nem dos representantes oficiais do Estado italiano:

Nunca formulei este slogan ["Nem com o Estado, nem com as BR"]. Pago impostos para o Estado italiano; não o pago, e nem quero pagá-lo, para as BR. Esse slogan nasceu da deformação da minha avaliação negativa da classe política italiana, avaliação que prossegue igual. Mas isso significa minha vontade de que essa classe dirigente mude. E não que tenha os sonhos das BR ... Não sou dissidente do Estado. [Italo] Calvino, durante a polêmica sobre a vilania dos intelectuais, lembrou, numa entrevista, que em meus livros pode-se entrever uma hesitação diante do Estado, mas que essa minha atitude "contra o Estado" deve ser tomada como uma desilusão, e não como uma aversão. ${ }^{9}$

Seu objetivo, insiste, era denunciar que: "Salvar a democracia, defender a liberdade, não ceder, não se render - hoje, diante das manchetes de cada acontecimento trágico que vemos nos jornais, são apenas palavras. Há um tipo de 
poder que não muda e que só mudará se se suicidar" (apud Collura, 2009, p.41-42).

Da mesma forma que não enxerga o Estado - e sim seus ocupantes - como um problema, Sciascia evidentemente não vê positividade na suposta defesa de tradições por meio de práticas criminosas, embora compreenda historicamente o fenômeno e seu vínculo com a tentativa de preservação da “identidade siciliana”. Endossa, portanto, a discussão acerca de tal identidade, tema recorrente e característico da literatura siciliana, presente em muitos de seus escritores.

Sciascia assume, dessa forma, o reconhecimento literário da identidade siciliana, articula-o à discussão acerca do crime organizado, retomando parcialmente a "questão meridional" enunciada por Antonio Gramsci (1987) e que aborda definições políticas da Itália unificada e seu significado no desequilíbrio social e econômico interno. Mais do que isso, a busca ficcional da sicilianidade, antes ou depois de Sciascia, nutre-se da história local e lembra a anexação forçada da ilha à Itália e a repressão violenta às revoltas, sobretudo à de 1848. Repete algumas marcas que denotam a especificidade da experiência histórica e cultural siciliana e reforçam o valor da honra viril e dos vínculos familiares fortes - influência clara de Pitrè. O passado e a tradição aparecem regularmente como elementos de salvação e resguardo perante as ameaças modernas e a paisagem, os costumes e a gastronomia, com seus pescados e doces, se impõem como locais de memória e de culto. Referências regulares à obsessão erótica e à inércia (provocada, em alguma medida, pelo sol e pelo calor tórrido) revelam a intromissão decisiva do ambiente. A paisagem dura e ruinosa também se traduz no comportamento e humor dos sicilianos: conversação silenciosa, tecida por meio de um repertório de gestos e de olhares incompreendidos pelos peninsulares que demarcam, mais até do que o recurso aos dialetos locais, a diferença de linguagem - efetivo abismo - e simbolizam a incomunicabilidade da Sićlia com o restante da Itália. A tensão permanente do passado irresolvido já produzira em Giovanni Verga - cuja obra é igualmente precursora na representação da sicilianidade - uma percepção pastosa do passado, em que a memória contamina irreversivelmente o presente, mistura-se a ele e impõe sua permanência na língua falada, nos costumes, nos valores, nas representações. Pétrea paisagem, pétrea identificação de um mundo de vencidos, cujo quotidiano se divide e se confunde entre o presente dificultoso e o passado inalterável e autêntico, mas já sem viço, já devastado pelos ventos ressignificadores da modernidade. 
Se o poder legalmente constituído não deriva da experiência histórica nem corresponde a ela, abre-se a brecha para a expansão de formas e instituições de controle alternativas; daí a centralidade da máfia na representação identitária, mesmo quando não nomeada. Por isso, Sciascia a recolhe da tradição literária insular e a explicita em sua obra. Sua representação do siciliano assume, dessa maneira, entonação dramática e de dupla intenção: de um lado, assegura o significado da pertença e da história da ilha como marcadas pela manifestação do passado; de outro, recusa o vínculo umbilical e irrestrito entre identidade siciliana e máfia, o que, para ele, levaria a naturalizar a associação criminosa e torná-la tolerável. Em outras palavras, mesmo que na origem a máfia se referisse às tradições sicilianas e as defendesse, sua ramificação pela Itália e para além da Itália demonstrou que o sentido criminoso prevaleceu sobre o tradicional e que a condição de guardiã da identidade - se é que um dia existiu - perdeu-se, mesmo que continue a ser reafirmada na retórica.

No lugar de ancorar o passado e a tradição numa suspeitíssima organização presente, Sciascia elege um lugar fictício para neles alocar a "Sicília real": a cidade imaginária de Regalpetra, presente em quase todos os seus relatos de ficção e exemplo categórico de suas preocupações e seus esforços estéticos e políticos. Para Claude Ambroise,

Mais do que a representação de uma realidade, Regalpetra é cristalização de uma experiência concreta daquela realidade. Não é um abstrato modelo sociológico proposto ao leitor ... mas sim o texto de uma experiência, a de Racalmuto, vivida em primeira pessoa e enriquecida por outras experiências trazidas de outras partes da Sicília. (Ambroise, 2001, p.XXVII-XXVIII)

Síntese de um passado atuante no presente, Regalpetra é também o testemunho de sua perda. Lá tudo ocorre por referência ao tempo passado, os usos e costumes tradicionais parecem preservados, mas o quotidiano foi afetado pelos ventos das mudanças. A população de Regalpetra parece paralisada pela dificuldade de ultrapassar o passado, mas é confrontada pela criminalidade do presente. Espaço simultaneamente de evasão e reflexão, de realidade e ficção, as tramas desenroladas em Regalpetra definem a posição de Sciascia na tradição verista da literatura siciliana e a presença forte da ficção de Luigi Pirandello em sua representação da sicilianidade: o realismo é tratado de forma irônica e sugere impostura, as verdades podem estar vivas, mas são irremediavelmente veladas; os enigmas são ilógicos e de resolução aparentemente impossível; é 
praticamente impossível discernir o falso do verdadeiro e os poderes públicos não são convincentes ou confiáveis.

A ambiguidade intencional e problematizadora da reinvenção urbana e siciliana de Sciascia não coloca em jogo, e em xeque, apenas a tradição literária local. Regalpetra é o laboratório da peculiaridade siciliana, o lugar onde se testa a adaptação de valores antigos à velocidade e à provisoriedade modernas, mas os dilemas sicilianos, na perspectiva de Sciascia, não se restringem a seus contornos ficcionalmente geográficos, nem mesmo à ilha. Expandiram-se para toda a Itália. Numa entrevista de 1976, questionado sobre a questão meridional, Sciascia constata a vastidão do descontrole:

para mim é perfeitamente natural tê-la [a questão meridional] vivido, vivê-la, representá-la. Nasci na Sicília, aqui vivo há 50 anos, sofro-a, "me dói” ("me dói a Espanha”, dizia Unamuno, como de uma parte do corpo). Sendo escritor, não poderia não "escrevê-la". Por outro lado, naturalmente busquei suas raízes ... Depois, num certo momento, a "questão", em sua especificidade, para mim, escritor, perdeu qualquer interesse, ainda que continuasse a tê-lo como cidadão ... Como escritor, vejo toda a Itália transformada em "questão meridional". (in Motta, 2004, p.14-15)

Apesar de ser possível enxergar, na declaração, a entonação do Sciascia-político, é inevitável reconhecer a persistência da discussão acerca de uma identidade que assumiu contornos criminalizados, de uma tradição que foi apropriada pela máfia; do moderno construído sobre os escombros do passado e que ainda recorre a eles para legitimar sua atuação ilícita. A percepção da Sicília em desassossego, do desconforto histórico e da expropriação do presente se nacionaliza e se universaliza sob a irrazão lúcida e intencional dos poderes clandestinos e de suas ramificações na legalidade. A máfia deixara definitivamente de ser uma preservação da "velha Sicília" para se transformar na lógica predominante e aterradora, em que as soluções são sempre precárias e sua exposição, impossível.

Para confrontar esse mundo corrompido, Sciascia realizou duas incursões na política institucional. Em 1975, lançou candidatura independente na lista das eleições municipais de Palermo pelo Partido Comunista Italiano (PCI). Foi eleito, mas renunciou pouco tempo depois, em protesto contra a aliança nacional do PCI com a Democracia Cristã (DC). Em 1979, convidado por Marco Panella, do Partido Radical, foi eleito deputado, posto que ocupou até $1986 .{ }^{10}$ 
Justificou seu retorno à política partidária por meio da indicação de seus temas e de suas preocupações centrais:

Ao aceitar ser candidato do Partido Radical nas próximas eleições para o parlamento nacional e europeu, sei que me contradigo em relação às declarações que até recentemente fiz sobre minha vocação para ser apenas escritor. Mas um homem vivo tem direito à contradição. Me agradaria, aliás, que a epígrafe de minha vida fosse simplesmente esta: "Contradisse e se contradisse". Uma contradição, aliás, em nome da vida, da esperança ... Romper os compromissos e os comprometimentos, os jogos de partidos, as máfias, os conchavos, os silêncios, a omertà; romper essa espécie de pacto entre a estupidez e a violência que tem se manifestado nos assuntos italianos. ${ }^{11}$

Coerentemente, seus poucos, breves e enfáticos pronunciamentos na Câmara trataram de assuntos relacionados aos pactos de governo que usualmente incluíam relações suspeitas e envolviam personagens e instituições vinculadas à máfia. $\mathrm{O}$ registro que privilegiou foi o da ética como princípio e regramento básico da ação política e da conduta pública:

sempre me ocupei da política: e sempre no sentido ético. Alguém dirá que esta é minha confusão ou meu erro: querer misturar a política com a ética. Mas seria uma confusão bastante saudável e um erro bastante feliz se os italianos, e principalmente neste momento, os cometessem. Eu decidi improvisadamente defender essa confusão e esse erro na forma mais explícita e direta de fazer política... ${ }^{12}$

A frase inicial do fragmento é categórica: "sempre me ocupei da política”. E o desfecho esclarece os vários graus de exposição dessa atuação: a política institucional é a forma direta, da mesma maneira que seus ensaios sobre questões do presente podem revelar posições e ideias. Foi também pela ficção, mesmo quando imediatamente motivada por fatos do cotidiano, que a contínua ocupação de Sciascia com a política se desenvolveu. A atuação parlamentar foi um breve entreato. A principal estratégia para defender a ética, reagir à corrupção mafiosa da identificação do siciliano e aos percalços do Estado italiano foi o recurso à ficção policial. Na combinação entre a atuação parlamentar e o trabalho literário, Sciascia definiu a extrema coerência de sua intervenção, consolidou as bases de sua luta e revelou as fronteiras porosas entre política e arte. 


\section{III.}

Ao recorrer à narrativa policial, Sciascia transpõe o debate acerca da sicilianidade para o contexto criminal, e assim denuncia o caráter ilegal e ilegítimo da máfia. Não é pelo crime que a Sicília pode sobreviver; sua humilhação passada e presente só pode ser contrabalançada pela defesa da razão. Essa, aliás, é a preocupação central e orgânica de sua obra, como reconhece em La Sicilia come metafora (A Sicília como metáfora), um de seus textos mais conhecidos (na origem, uma entrevista): “Todos os meus livros são, na prática, um só. Um livro sobre a Sicília, que toca a ferida dolorida do passado e do presente, e que se organiza como a história de uma contínua derrota da razão" (Sciascia, 1979, p.89).

A empreitada pela razão que caracteriza a discussão política de Sciascia é a mesma que o faz optar pela precisão lógica do método analítico - marca do policial desde a origem em Edgar Allan Poe - e dar-lhe papel de protagonista, mesclando a indagação identitária e a denúncia política a um esforço iluminista (e, mais especificamente, voltaireano). Afinal, a narrativa policial conduz sempre das pistas à razão, mesmo que se trate de uma razão vencida, que não será de todos conhecida - e, se o for, será logo calada ou comunicada exclusivamente por meio de olhares, como reza a boa tradição siciliana e como fazem os inúmeros personagens de Sciascia (e de tantos outros autores sicilianos). Porque, no centro do policial de Sciascia, não está a busca de uma verdade desconhecida. A trama criminosa de A cada um o seu é conhecida de todos e, no entanto, há alguém disposto a investigá-la, não para descobrir a verdade, e sim para expô-la. Não consegue, acaba morto e tachado de "cretino". Resta o silêncio, cuja explicação, diz Cesare Segre, está na disposição de Sciascia de representar a sicilianidade e o espaço aberto para a proliferação da instituição criminosa. Ao questionar os motivos que levaram o personagem Laurana, de A cada um o seu, a investigar o crime, Segre afirma:

Creio que a resposta esteja na concepção que Sciascia tem da sociedade siciliana. Todos, nesta sociedade, têm papéis precisos e posições precisas na política e na disposição geral. A ilegalidade e a corrupção vigentes sob a ordem aparente e os papéis oficiais são em boa parte construídos, são conhecidos em linhas gerais, mas pode-se aludir a eles apenas na forma da indiscrição sussurrada ou da maledicência. (Segre, 2006, p.25)

A lógica do policial é posta de ponta-cabeça, e o ocasional leitor de $A$ cada um o seu e de tantos outros relatos de Sciascia, lembra Sandrone Dazieri, pode perguntar-se: 
Mas, enfim, se é um policial, onde está a investigação, onde está a construção racional, onde estão as associações, o indício que depois se conecta com outro indício e, ao final, constrói uma cadeia de lógica férrea, que talvez não leve à captura do culpado, mas pelo menos à individuação, à construção de um quadro racional que explique o crime? Não há ... Mas [o leitor] se dá conta de algo diferente: que, nessa procura, nessa viagem que nosso professor Laurana faz ao interior dessa sociedade, lentamente, cada vez que dá um passo, é como se uma pequena luz surgisse de seus movimentos; é uma luz que, por sua vez, revela um pouco tudo aquilo que está no entorno. Revela como funciona a sociedade, não apenas a região, a pequena região, mas tudo que a rodeia: a cadeia de poderes, a cadeia de comando, a cadeia da omertà. Revela como funciona o crime naquela parte, o que é o crime, como sua origem é extremamente próxima da própria sociedade a ponto de, para se ter uma ideia, o oculista, que ele [Laurana] vai procurar e é o pai de um dos dois assassinados, lhe dizer: Veja, entre nós se diz: "chora o morto e ajuda o vivo". (Dazieri, 2006, p.32-33)

O improvisado detetive Laurana, professor, cumpre seu papel de tentar expor à luz da lei aquilo que, ao menos em parte, é conhecido de todos. Sciascia, escritor, identicamente tenta expor o contexto siciliano à outra luz, a da razão. Para tanto, expande os limites do gênero e o varia, ultrapassa o ambiente do crime e concerne o conjunto da sociedade: assim, a narrativa ficcional se torna, aos poucos, um quadro sociológico e moral, em que espaços públicos e íntimos, rituais de amizade e de compromisso familiar e político, estratégias do dizer e do não-dizer se confundem e explicam o universo criminal. $\mathrm{O}$ estranho policial de Sciascia desmonta o próprio conceito de relato de enigma, destaca Ambroise:

No policial canônico, a figura do investigador indica que os fatos, as informações, os indícios são legíveis, compõem uma narrativa. E se se tornam um texto, de tal forma que o investigador também pode parecer empenhado na construção do relato, é porque a realidade enquanto tal se presta a ser lida, decifrada. À medida que o livro se desenvolve surgem complicações sucessivas, mais ou menos completas, de uma transcrição: do acontecimento (o crime) à queda (o relato conclusivo do detetive). Para o leitor de policiais, a figura do investigador funciona como uma garantia: ele lê a realidade, eu leio o livro; no fundo, em nossas duas leituras paralelas está a verdade. Ao contrário, parecerá lógico, num escritor que não assegure a sobrevivência de seus investigadores, que o texto perca em transparência, exija uma leitura mais profunda, talvez uma ou mais releituras ... Se o 
investigador morre antes de levar a termo seu trabalho ou caso se afaste, a decifração da realidade fica necessariamente incompleta. A sua e a minha leitura não coincidem mais. Texto e realidade não se sobrepõem mais. Onde está verdade? ${ }^{13}$

Sciascia delimita o lugar possível da verdade e sua substituição pelo falso relato ou pelo silêncio. $O$ procedimento requer também do leitor uma posição mais ativa diante do texto, conforme nota Ambroise: "O leitor não vive mais na ilusão de uma presença imediata das pessoas e das coisas; ele se vê confrontado com a profundidade do texto, necessariamente ambíguo, que exige ser decifrado. Em termos literários, significa a promoção, de fato, do texto e o naufrágio da poética em geral realista que, habitualmente, preside o policial" (Ambroise, 2000, p.XXXIX). No lugar do efeito de realidade a que a narrativa policial usualmente recorre, instala-se a ideologia e a denúncia da impostura: "o policial é esvaziado de sua pretensa verdade, que cede espaço a toda uma série de estereótipos ... O policial dá forma à impostura da verdade e, enquanto forma, é violentado quase até sua total abolição" (Ambroise, 2000, p.XXXVIII-XLIII).

Quanto mais distante do "esforço realístico", mais perto do político e da tentativa de romper as lentes que tentam ocultar as relações subterrâneas da sociedade. O próprio Sciascia explicita tal disposição ao relembrar diversos crimes políticos que ficaram sem solução: “A Itália é um país sem verdade. Ao contrário, veio à luz uma regra: nenhuma verdade jamais será conhecida se atinente a fatos criminosos que tenham, ainda que minimamente, relação com a gestão do poder" (Sciascia, 2001b, p.730). Diante da exclusão da verdade, prevalece o modelo irônico de Sciascia - a mesma ironia explicitada no emprego que faz do gênero policial e nas revelações precárias de seus detetives, que atuam em romances, destaca Nicoletta Vallorani, "construídos sobre realidades históricas muito precisas e radicadas no social ... doloroso". ${ }^{14}$ Sciascia caracterizou o método que baseia seu policial (e o motivo da escolha do gênero) em La Sicilia come metafora:

Da escritura-engano, oferecida ao cidadão e a mim mesmo, passamos à escritura-verdade, e estou convencido de que ... a única forma possível da verdade é a arte. $\mathrm{O}$ escritor revela a verdade decifrando a realidade e levando-a à superfície; num certo sentido, simplificando-a, ainda que a torne mais obscura, pois assim é a própria realidade ... Não se trata mais da obscuridade e do que não foi dito, daquilo que não foi explicitado, mas, ao contrário, do dito e explicitado. Eis por 
que utilizo constantemente o "discurso" do romance policial, esta forma que tende à verdade dos fatos e à denúncia do culpado. (Sciascia, 1979, p.87)

Ao apelar à alegoria para construir a verdade, a narrativa policial de Sciascia mostra, segundo a análise do romance Todo modo por Pier Paolo Pasolini, a associação entre o poder e o crime:

A pirâmide do poder, monolítica por fora, extremamente complexa, labiríntica, monstruosa por dentro. De fora, defronte a tal pirâmide, o "bom" homem que julga sem moralismo. Mas em Todo modo há uma novidade: o juiz, quase casual - posto que está quase por acaso diante da pirâmide, e por acaso é levado para dentro dela, entre seus incompreensíveis mecanismos - se torna justiceiro. Esse romance policial de Sciascia ... é ainda, creio, uma sutil metáfora dos últimos 30 anos de poder democrata-cristão, fascista e mafioso, com uma pitada final de cosmopolitismo tecnocrático ... Trata-se de uma metáfora profundamente misteriosa, como reconstituída num universo que elabora os dados da realidade até a loucura. (Pasolini, 1979, p.599)

Pasolini ainda destaca o que considera a "microfísica" do poder e da verdade representados na ficção de Sciascia e que Fabio Moliterni identifica à "vocação profunda da obra" do escritor de Regalpetra, cuja concepção de literatura equivale à identificação de um "contrapoder" do relato de enigma, dada sua relação "com a verdade e com a justiça". Dessa forma, Sciascia penetra completa Moliterni - no território da micro-história:

Do ponto de vista morfológico, a escrita de Sciascia escapava das classificações ou das taxonomias excessivamente rígidas que tendiam a fixá-la ... num binômio fechado, irredutível: vocação narrativa e ensaísmo; disposição ao documentário e ao romance policial, ficção romanesca e apólogo; imaginação e preocupação historiográfica; literatura e história. Quando me parece que, ao contrário, o que fermentava e até dirigia sua escrita era exatamente a interpenetração, a fusão, a hibridização e a dependência recíproca dos dois polos ... Em suas investigações histórico-judiciais, seu impulso à reescritura de acontecimentos ou pessoas realmente existentes se ligava à precisão filológica e ao "nu e cru" exame das fontes, desmistificando as mentiras sedimentadas nos arquivos da historiografia oficial, restaurando uma verdade possível (linguística) da experiência reconstruída na perspectiva dos "vencidos". Entre a realidade e a ficção, sem renunciar à busca da verdade e da esperada polêmica que caracteriza sua prática literária, Sciascia recorria a esquemas romanescos na animação de seus personagens, no cuidado 
com os detalhes, e consumava, por meio de sua micro-história, o afresco histórico (ou histórico-linguístico) marcado por uma pátina literária e estilística de desenvolvimento complexo e necessário. (Moliterni, 2007, p.13-14, 18, 60)

Sua escrita se equipara a um "tratado do policial como tratado político sobre a contemporaneidade" e a verdade aparece numa versão "esfumaçada" que, além de favorecer o uso político, mantém o sentido imaginativo e estético da representação ficcional, responsável por pintar, na metáfora de Carlo Ginzburg (2001), a realidade "ao revés". A estratégia de representação resulta de uma combinação peculiar, mas eficaz: narrativa policial, panfleto político, método histórico. A experiência vivida é atualizada, condensada e cristalizada na ficção e fornece as referências necessárias para pensar o presente político e social. A escolha estilística garante o sucesso da denúncia e a força da verdade anunciada, conectando obra e autor sobre a base da narrativa policial.

\section{IV.}

Passados quase 50 anos da carta citada no início deste texto, talvez devamos dar razão apenas parcial a Calvino. De fato, o policial de Sciascia não é um clássico do modelo europeu ou do americano, no sentido de que não há resolução plena ou consolação. A verdade e a justiça não prevalecem, nem são asseguradas por um sistema legal que vise a seu respeito e cumprimento. Mas o desvendamento do enigma, mesmo se abafado na trama, inquieta o leitor pelas denúncias e acusações que implica e que não preservam ninguém - indivíduos ou instituições, todos aparecem como criminosos e impunes (sobretudo, mas não só, o Estado, a Igreja). Sciascia, portanto, não chega propriamente a "demonstrar a impossibilidade do policial no contexto siciliano", o que implicaria assumir a perspectiva pessimista de que a consciência ou a revelação são impossíveis, algo que o iluminismo radical de Sciascia não poderia admitir. Mesmo que precariamente, a razão investigadora é vitoriosa, porque expõe as sórdidas fissuras da sociedade siciliana e os desvãos do poder corrupto. E a narrativa policial "desmontada" renasce ressignificada e deixa de ser mera fuga do pensamento, simples entretenimento, para se tornar ato político e ficção histórica.

Na combinação entre o entretenimento e a escritura-denúncia, Sciascia constrói uma Sicília simultaneamente bela e corrupta: pétrea na paisagem e na incapacidade de superar as mazelas históricas e a dinâmica da política 
consumada nas alianças e nos conchavos criminosos. Em ambos, a mesma percepção da ambiguidade da identificação pelo silêncio - o silêncio que tinha a função de proteger a Sicília e os sicilianos da interferência indevida dos "continentais" e que contribuiu decisivamente para a propagação da associação criminosa. A caracterização de uma linguagem peculiar, consumada através do olhar e inacessível aos não-sicilianos, reitera o que hoje é quase uma caricatura, mas que persiste real: a impermeabilidade da Sicília, a limitada comunicação, o mascaramento travestido de identidade continuamente intransitiva.

No conto "O mar cor de vinho", um professor siciliano divide a cabine do trem com italianos do norte, a caminho da Sicília. Passo a passo, o personagem encena todas as características atribuídas aos sicilianos: a afetividade, a desconfiança, a mistura de apreço e depreciação da própria terra. Perguntado pelo nortista sobre a máfia, o siciliano insiste em negar sua existência:

“Tem máfia?", perguntou o engenheiro.

"Máfia?", disse o professor, espantado como se lhe tivessem perguntado se na sua cidade as pessoas comiam polenta e tomavam grappa. "Que máfia? Bobagens."

"E estas coisas?", perguntou o engenheiro mostrando no jornal do dia anterior a manchete de quatro colunas que dizia "A máfia não quer as represas".

"Bobagens", novamente cortou o professor.

O engenheiro pensou "Um homem culto, gentil, bom pai de família; e não quer falar da máfia, espanta-se até que alguém queira falar, como se falando estivesse dando importância a coisas menores; bobagens, enfim. Estou começando a entender a máfia, realmente é um drama". ${ }^{15}$

Não paradoxalmente, a revelação por Sciascia vem do reconhecimento, amargo e talvez heroico, de que é pelo silêncio que se pode compreender a Sicília. E esse silêncio é ambíguo: fruto de uma derrota histórica e ocasional refúgio, pretende afirmar a diferença e acaba por determinar o isolamento. Identidade que corre o risco de ser percebida apenas no espelho, a sicilianidade opera subterraneamente às ficções policiais de Sciascia, conformando um percurso que, como em toda narrativa de enigma, une as pistas à razão. O resultado, porém, é uma razão distorcida e quase sempre injusta. Os ecos inevitavelmente críticos da representação instauram, porém, o espaço da história, que se manifesta entre os crimes do texto e os crimes verdadeiros. 


\section{REFERÊNCIAS}

AMBROISE, Claude. Polemos. In: SCIASCIA, Leonardo. Opere. 1971-1983. Milano: Bompiani, 2001.

. Verità e scrittura. In: SCIASCIA, Leonardo. Opere. 1956-1971. Milano: Bompiani, 2000.

BARNES, Melvyn. Murder in Print. London: Barn Owl Books, 1986.

BÉRARD, C. Casalé. Riscrittura come ironia da Pirandello a Sciascia. In: PICONE, Michelangelo; DE MARCHI, Pietro; CRIVELLI, Tatiana (Org.) Sciascia scrittore europeo. Berlin: Birkhäuser, 1994.

BOILEAU, Pierre; NARCEJAC, Thomas. O romance policial. São Paulo: Ática, 1991. BOURDIER, Jean. Histoire du roman policier. Paris: Éd. de Fallois, 1996.

CAMILLERI, Andrea. Un onorevole siciliano: le interpelanze parlamentari di Leonardo Sciascia. Milano: Bompiani, 2009.

COLLURA, Matteo. Alfabeto Sciascia. Milão: Longanesi, 2009. Il maestro de Regalpetra: vita di Leonardo Sciascia. Milano: Tea, 1996.

CREMANTE, Renzo; RAMBELLI, Loris (Org.) La trama del delitto: teoria e analisi del racconto poliziesco. Parma: Pratiche, 1980.

DAZIERI, Sandrone. Il primo scrittore di noir italiano. In: D'ALESSANDRA, Marcello; SALIS, Stefano (Org.) Nero su giallo: Leonardo Sciascia eretico del genere poliziesco. Milano: La Vita Felice, 2006.

GINZBURG, Carlo. Olhos de madeira: nove reflexões sobre a distância. São Paulo: Companhia das Letras, 2001.

GRAMSCI, Antonio. A questão meridional [1926]. Rio de Janeiro: Paz e Terra, 1987. GRIMALDI, Laura. Il giallo e il nero: scrivere suspense. Parma: Pratiche, 1996.

LO VERME, Angelo. La mafia, la Sicilia e Leonardo Sciascia. Empoli: Ibiskos-Ulivieri, 2006.

LUPO, Salvatore. Che cos'è la mafia: Sciascia e Andreotti, l'antimafia e la politica. Roma: Donzelli, 2007

. História da Máfia: das origens aos nossos dias. São Paulo: Ed. Unesp, 2002.

MOLITERNI, Fabio. La nera scrittura: saggi su Leonardo Sciascia. Gorgonzola: B. A. Graphis, 2007.

MOTTA, Antonio. Giorni felici con Leonardo Sciascia. Bellinzona: Casagrande, 2004.

PASOLINI, Pier Paolo. Descrizione di descrizioni. Milano: Mondadori, 1979.

PETRONIO, Giuseppe. Sulle trace del giallo. Roma: Gamberetti, 2000.

SALIS, Stefano. La mafia in letteratura, Leonardo Sciascia e Il giorno della civetta. In: D’ALESSANDRA, Marcello; SALIS, Stefano (Org.) Nero su giallo: Leonardo Sciascia eretico del genere poliziesco. Milano: La Vita Felice, 2006.

SCIASCIA, Leonardo. L'affaire Moro. In: . Opere II (1971-1983). Milão: Bompiani, 2001c. 
SCIASCIA, Leonardo. Breve storia del romanzo poliziesco. In: . Cruciverba.

Opere. 1971-1983. Milano: Bompiani, 2001a. . A ciascuno il suo. Milano: Adelphi, 1988. . Il giorno della civetta. Milano: Adelphi, 1993. . O mar cor de vinho. São Paulo: Berlendis \& Vertecchia, 2001d. 2001b. Nero su nero [1979]. In: Opere. 1971-1983. Milano: Bompiani,

. La Sicilia come metafora. Milano: Mondadori, 1979. . Todo modo. Torino: Einaudi, 1974.

SEGRE, Cesare. A ciascuno il suo di Sciascia. L'investigatore 'cretino'. In: D’ALESSANDRA, Marcello; SALIS, Stefano (Org.) Nero su giallo: Leonardo Sciascia eretico del genere poliziesco. Milano: La Vita Felice, 2006.

VALLORANI, Nicoletta. Il giorno della civetta, non 'solo' un poliziesco. In: D’ALESSANDRA, Marcello; SALIS, Stefano (Org.) Nero su giallo: Leonardo Sciascia eretico del genere poliziesco. Milano: La Vita Felice, 2006.

VERGA, Giovanni. Os Malavoglia. São Paulo: Ateliê Editorial, 2002.

\section{NOTAS}

${ }^{1}$ Mestre, Doutor e Livre Docente em História Social pela Universidade de São Paulo (USP).

${ }^{2}$ A carta de Calvino é de novembro de 1965 e antecede em poucos meses a primeira edição do livro de Scascia. "Policial que não é um policial": no original, "giallo non giallo"; na Itália, a narrativa policial é chamada de giallo (amarelo) em função da cor da capa das edições populares que difundiram o gênero (SCIASCIA, 1988, p.3). As traduções de textos não publicados em português são nossas.

${ }^{3}$ Os propósitos e limites do texto não permitem, infelizmente, discutir com detalhes a história da narrativa policial e a abordagem de autores que se empenharam em compreender a dinâmica do gênero. Para mais esclarecimentos, ver, entre outros: BARNES, 1986; BOILEAU; NARCEJAC, 1991; BOURDIER, 1996; CREMANTE; RAMBELLI, 1980; GRIMALDI, 1996; MOLITERNI, 2007; PETRONIO, 2000.

${ }^{4}$ SCIASCIA, 1993, p.106-108. A publicação original de O dia da coruja é de 1961, 5 anos antes de A cada um o seu.

${ }^{5}$ SCIASCIA, 2001, p.1196. O livro de Carlo Emilio Gadda a que Sciascia se refere é La cognizione del dolore, de 1963. É importante notar que Sciascia escreve posteriormente à consolidação do chamado hard-boiled, variação da narrativa policial desenvolvida nos Estados Unidos e associada, entre outros, às obras de Dashiell Hammett e Raymond Chandler. Embora Sciascia reconheça a importância desses autores, ele não os segue: seus procedimentos textuais são distintos, a linguagem empregada é essencialmente diferente e, 
sobretudo, não há, em Sciascia, um elemento central do hard-boiled: o investigador imiscuído no mundo do crime; ao contrário, para ele, esse mundo é impenetrável e o investigador delimita continuamente sua estranheza em relação a ele.

${ }^{6}$ SCIASCIA, 2001. O conto "Filologia" foi escrito em 1963.

${ }^{7}$ A Comissão Antimáfia (Commissione Parlamentare di inchiesta sul fenomeno della mafia e sulle altre associazioni criminali, anche straniere) é um órgão bicameral do parlamento italiano, que procurou estimular e sistematizar as investigações acerca das atividades das organizações criminosas. Sciascia nem sempre concordou com as decisões e as atitudes da Comissão e chegou a acusar seus membros de "profissionais da Antimáfia", considerando-os, com algum exagero, mais preocupados com a exposição midiática do que com o combate ao crime organizado. Veja-se: LUPO, 2007; LO VERME, 2006.

${ }^{8}$ Apud: LUPO, 2002, p.19. Pitrè diz que mafiusu e mafiusedda eram termos originários de bairros populares de Palermo e significavam, respectivamente, "beleza" ou "excelência" e "moça bela e orgulhosa". Salvatore Lupo observa, a partir da leitura de dois dicionários do século XIX - o Dizionario siciliano, de G. Traina (1868) e o Nuovo dizionario siciliano-italiano, de V. Mortillaro (1875) -, que vários contemporâneos de Pitrè discordavam da origem local dos termos e indicavam que a palavra tinha procedência nortista e sentido originalmente pejorativo.

${ }^{9}$ Apud: CAMILLERI, 2009, p.21-22. “BR”: Brigate Rosse (Brigadas Vermelhas), no original. Tal polêmica nasceu sobretudo de dois episódios: o assassinato, pelas Brigadas Vermelhas, do operário Guido Rossa, que havia denunciado atos terroristas, e do pedido de afastamento do júri responsável pela sentença no processo contra Renato Curcio e outros chefes brigadistas, em maio de 1977 (todos os membros do júri se retiraram alegando depressão). Diversos intelectuais apoiaram as ações ou disseram compreendê-las; Sciascia se opôs frontalmente ao que considerou "omissão" dos jurados e defendeu a denúncia de Rossa. A polêmica envolveu nomes expressivos da literatura italiana, como Eugenio Montale e Italo Calvino, citado por Sciascia.

${ }^{10}$ Apesar de se filiar e representar o PCI, Sciascia nunca endossou as posições comunistas e sempre teve atritos com o partido. A polêmica decisão de renunciar ao mandato para o qual fora eleito foi assim explicada por ele: "Parecia-me correto e necessário pôr fim, naquela cidade [Palermo], ao poder da DC, que então durava 30 anos ... Demorei 18 meses para entender que o PCI não estava disposto a ocupar o papel de oposição que lhe cabia no conselho comunal ... A verdade é que não era possível combater em Palermo e manter a aliança em Roma". Anos depois, apresentou-se como candidato independente na lista do Partido Radical e foi eleito para o Parlamento Europeu e para a Câmara dos Deputados pela circunscrição de Turim, Milão e Roma. Abriu mão do mandato europeu e optou pela Câmara. A compreensível curiosidade de sua eleição veio do fato de ser eleito pelo centro-norte da Itália e não ter conseguido se eleger pela própria Sićlia: candidato também na ilha, recebeu apenas 636 votos em Racalmuto, sua cidade-natal, e 3.634 em toda a província de Agrigento, menos de um terço da votação recebida pelo candidato democrata-cristão. Cf. CAMILLERI, 2009, p.11-13. Ver também COLLURA, 1996. 
${ }^{11}$ SCIASCIA, 1979, p.24-25. Durante seu mandato, Sciascia se pronunciou apenas 19 vezes, entre questionamentos, interpelações e resoluções. Onze desses pronunciamentos foram comprovadamente escritos por ele. A revista Euros os reuniu no número duplo 3-4 (maio-ago. 1993). Em 2009, foram organizados, editados e comentados por Andrea Camilleri.

${ }^{12}$ Apud: CAMILLERI, 2009, p.26. Exemplo significativo da interferência de Sciascia nos assuntos candentes da vida pública italiana foi sua manifestação diante do sequestro e assassinato (entre 16 de março e 9 de maio de 1978) do ex-primeiro-ministro democrata-cristão Aldo Moro pelas Brigadas Vermelhas. Além de se envolver em diversas polêmicas - através da imprensa e ainda durante o sequestro - Sciascia finalizou, já em agosto de 1978, o livro L'affaire Moro, publicado em seguida simultaneamente na Itália e na França. A ideia de Il giorno della civetta (1961), por exemplo, nasceu de um debate parlamentar a que Sciascia assistiu. A denúncia das ações e alianças políticas do PCI está por trás de Il contesto (1971), e a crítica à Democracia Cristã fundamenta Todo modo (1974).

${ }^{13}$ AMBROISE, 2000, p.XXXVIII-XXXIX. Em A cada um o seu, o investigador é morto antes do fim; em Todo modo (1974), ele se afasta da investigação.

${ }^{14}$ VALLORANI, 2006, p.96-97. Ver também BÉRARD, 1994.

${ }^{15}$ SCIASCIA, 2001d, p.66. A publicação original de “O mar cor de vinho” é de 1967.

Artigo recebido em 20 de outubro de 2015. Aprovado em 19 de janeiro de 2016. 